\title{
The first report of South American edrioasteroids and the paleoecology and ontogeny of rhenopyrgid echinoderms
}

Colin D. Sumrall, Susana Heredia, Cecilia M. Rodríguez, and Ana I. Mestre

Acta Palaeontologica Polonica 58 (4), 2013: 763-776 doi: http://dx.doi.org/10.4202/app.2011.0108

A new species of rhenopyrgid edrioasteroid Rhenopyrgus piojoensis sp. nov. is described form the Silurian (Lower Ludlow) Los Espejos Formation in the Precordillera of Argentina. This species is the first reported edrioasteroid from South America. Rhenopyrgids are widely distributed in Ordovician through Devonian deposits of most continents. Numerous juvenile specimens show that the general bodyplan is organized early in ontogeny and that the pedenculate zone lengthens with age. Phylogenetic analysis shows that rhenopyrgids are more closely related to edrioasterid edrioasteroids such as edrioblastoids and cyathocystids than to pyrgocystid isorophids.

Key words: Echinodermata, Edrioasteroidea, Rhenopyrgidae, ontogeny, paleoecology, Silurian, South America.

Colin D. Sumrall [csumrall@utk.edu], Department of Earth and Planetary Sciences, University of Tennessee, Knoxville, 37996, USA; Susana Heredia [sheredia@uns.edu.ar ], Cecilia M. Rodríguez [mceciliarodriguez@gmail.com], and Ana I. Mestre [amestre@unsj.edu.ar], CONICET, Instituto de Investigaciones Mineras, Universidad de San Juan, Urquiza y Liberador, 5400, San Juan, Argentina.

This is an open-access article distributed under the terms of the Creative Commons Attribution License (for details please see creativecommons.org), which permits unrestricted use, distribution, and reproduction in any medium, provided the original author and source are credited. 
